\title{
AGENDA REFORMASI BIROKRASI UNTUK MEMBEBASKAN BUDAYA PUNGUTAN LIAR
}

\author{
Oleh: SRI MUJIARTI ULFAH
}

\begin{abstract}
ABSTRAK
Pungutan liar merupakan budaya buruk namun telah lama ada dan tetap dipraktikkan meskipun agenda reformasi birokrasi merupakan program prioritas pemerintah pasca orde baru. Praktik pungutan liar ini menambah daftar panjang patologi birokrasi di Indonesia sehingga jika tidak segera diselesaikan akan melahirkan kebangkrutan birokrasi. Tantangan Reformasi birokrasi adalah politik pragmatis saat ini yang kental dipraktikkan oleh para politisi, politik kepentingan melahirkan reformasi birokrasi yang disetting sesuai kepentingan penguasa. Sehingga penting bagi pemerintah untuk melepaskan diri dari politik kepentingan aar agenda reformasi birokrasi berjalan sesuai dengan tujuannya.
\end{abstract}

\section{Kata kunci: Reformasi birokrasi, pungutan liar, politik}

\section{PENDAHULUAN}

Operasi Tangkap Tangan praktek suap di Kementrian Perhubungan tak terlalu mengejutkan, karena sudah jama diketahui masyarakat bahwa berbagai macam urusan masyarakat yang berurusan dengan transfortasi, baik itu pembuatan izin operasional berbagai moda transportasi, pernerbitan sertifikat operator penerbangan, mengeluarkan sertifikat kesehatan personil penerbangan dll.

Dari hasil penyelidikan diketahui bahwa suap terjadi untuk mempercepat pengurusan perizinan. Meskipun saat ini pemerintah telah mengembangkan e-Government dalam mendekatkan diri kepada masyarakat, dan untuk meminimalkan praktek pungutan liar, namun ternyata banyak celah yang bisa dimanfaatkan untuk memperkaya diri. Begitupun halnya di Kementrian Perhubungan menurut Kombes Awi Setiyo "Semua izin diurus online, mereka coba potong prosedur supaya bisa dapat uang," (bbc.com. 11/10/16. Bahkan tak tanggung-tanggung dana yang terindikasi merupakan hasil suap berkisar milyaran dengan bayaknya orang yang terlibat, ini diindikasikan dengan beberapa catatan nama serta nominal tujuan uang tersebut.

Pemerintah kemudian membuat satuan tugas sapu bersih pungutan liar (satgas saber pungli) penanggung jawab menteri Menteri Koordinator Politik, Hukum, dan Keamanan, Wiranto. Satgas anti pungli ini merupakan operasi Satuan Tugas Sapu Bersih Pungutan Liar (Satgas Saber Pungli) akan bersifat lintas lembaga dan unit. Yaitu, kepolisian, kejaksaan, dan Kementerian Koordinator Politik, Hukum, dan Keamanan akan bersama-sama mengisi susunan organisasi Satgas Saber Pungli.

\section{PUNGUTAN LIAR MERUPAKAN PATOLOGI BIROKRASI}

Menurut Samudra Wibawa (2005: 154) mengungkapkan bagaimana pungutan liar merupakan kelanjutan dari praktik upeti sejak jaman kerajaan majapahit. Para pejabat rendahan secara periodik harus menyetorkan kepada pejabat diatasnya. Dan upeti yang disetorkan tersebut berasal dari warga masyarakat. Kondis tersebut dianggap sebagai hal yang lumrah dikarenakan ini 
merupakan suatu kondisi yang dianggap budaya pada waktu itu meskipun bagi masyarakat praktik tersebut tetap meyengsarakan.

Beda halya dengan apa yang terjadi saat ini. Secara peraturan pungutan liar merupakan praktik yang illegal sehingga bagi yang menyuap atau yang disuap telah melakukan pelanggaran hukum. Para administrator yang kehadirannya seharusnya mampu melahirkan pengayoman dan membantu urusan masyarakat namun dengan praktik pungli ini malah membawa kepada kesengsaraan masyarakat. Pelayanan yang seharusnya mampu dihadirkan dengan cepat, efektif dan efisien bagi masyarakat tapi malah dipersulit bahkan tak jarang mematok tarif khusus untuk kompensasi pelayanan.

Birokrasi menurut kamus umum bahasa Indonesia adalah sistem pemerintahan yang dijalankan oleh pegawai pemerintah karena telah berpegang pada hierarki dan jenjang jabatan. Atau dalam definisinya yang lain, birokrasi adalah cara bekerja atau susunan pekerjaan yang serba lamban, serta menurut tata aturan yang banyak laku-likunya (Poerwadarminta, Kamus umum bahasa Indonesia; 1987:144.)

Menurut perspektif Administrasi Publik, birokrasi dapat di pahami sebagai Badan atau organisasi pemerintahan yang melaksanakan layanan public yang profesional, efektif, efisien, dan produktif. Birokrasi mesti melaksanakan tugas sesuai aturan, cepat, tepat, mudah, murah, dan menghasilkan. Pandangan ini diperkuat oleh Agus P \& Wahyudi K (2009) Birokrasi merupakan mesin organisasi dan kebijakan publik yang sangat penting.

Sebagai pemberi pelayanan, maka birokrasi berada di garis terdepan langsung bersinggungan dengan masyarakat, memenuhi kebutuhan masyarakat. Sehingga untuk mengukur bagaimana baik dan bersihnya pemerintah dapat melalui performance birokrasinya. Namun dari Pengalaman dan kinerja birokrasi dari berbagai Negara telah melahirkan dua pandangan yang saling bertentangan terhadap birokrasi. Pandangan pertama melihat birokrasi sebagai kebutuhan, yang akan meng-efesien-kan dan men-efektif-kan pekerjaan pemerintahan. Pandangan kedua, melihat birokrasi sebagai "musuh" bersama, yang kerjanya hanya mempersulit hidup rakyat, sarangnya korupsi, tidak melayani, cenderung kaku dan formalistis, penuh dengan arogansi (yang bersembunyi di balik hukum) dan sebagainya.

Memang munculnya pandangan tersebut bukan tanpa alasan, karena permasalahan birokrasi tetap merupakan masalah sentral yang dihadapi oleh Negara. Padahal secara konseptual, birokrasi merupakan badan yang netral. Faktor diluar birokrasilah yang menentukan wajah birokrasi menjadi menjadi baik atau jahat, yaitu manusia yang akan menjalankan dan system yang dipakai, dimana birokrasi itu hidup dan bekerja. Artinya jika sistem (politik, pemerintahan dan sosial budaya) yang dipakai oleh suatu negara adalah baik dan pejabat birokrasi adalah orangorang yang baik, maka birokrasi menjadi sebuah badan yang baik dan efektif. Sebaliknya, jika birokrasi hidup dalam system yang jelek, hukumnya lemah, serta ditunggangi oleh para pejabat yang tidak jujur, maka birokrasi akan menjadi buruk dan menakutkan bagi rakyatnya.

Warsito Utomo (2007) menggambarkan ketika kita mendalami dan hidup dalam aktivitas birokrasi pemerintahan, maka kita akan sangat mengenal dan familiar dengan apa yang disebut dengan bureaupathology, yakni penyakit birokrasi. Penyakit birokrasi terdiri dari birokratism dan bureaunomia. Penyakit birokratism merupakan penyakit birokrasi yang berkaitan dengan pelayanan pemerintah yang menyangkut system prosedur yang sangat berbelit-belit, memakan waktu, biaya dan tenaga. Sedangkan bureaunomia tidak saja mempengaruhi pelaksanaan tekhnis operasional pemerintahan, tetapi lebih berpengaruh terhadap derajat tingkat kebijakan pemerintah atau formulasi kebijakan pemeritah. Bureaunomia dilakukan oleh kekuatan-kekuatan politik untuk mempengaruhi birokrasi pemerintahan didalam melayani masyarakat. Bureaunomia menanamkan 
pengaruhnya didalam birokrasi pemerintahan dengan mendudukkkan orang-orang partai yang bukan birokrasi profesional didalam jajaran birokrasi ataupun memberikan privilege pada aparat birokrasi yang berafiliasi dengan kekuatan partainya.

Dampak yeng terjadi dengan adanya bureaunomia adalah, pertama, birokrasi dan birokrat kita menjadi tidak netral lagi. Formulasi dan implementasi kebijakan lebih ditentukan oleh kekuatan dapur politik partai daripada dapur pemerintahan. Kedua, birokrasi dan birokrat kita lebih berorientasi kepada kepentingan keinginan partai politik daripada komponen perangkat daerah. Ketiga, birokrat dan birokrasi melakukan tindakan-tindakan yang tidak elegant sesuai dengan profesionalismenya, tetapi bergerak seperti massa sebagaimana politik praktis (Warsito, 2007).

Indikator buruknya kerja birokrasi pada mumnya berfokus pada terjadinya korupsi. Korupsi atau rasuah adalah tindakan pejabat publik, baik politisi maupun pegawai negeri, serta pihak lain yang terlibat dalam tindakan itu yang secara tidak wajar dan tidak legal menyalahgunakan kepercayaan publik yang dikuasakan kepada mereka untuk mendapatkan keuntungan sepihak. (ti.or.id).

Jenis tindak pidana korupsi di antaranya; memberi atau menerima hadiah atau janji (penyuapan); penggelapan dalam jabatan; pemerasan dalam jabatan; ikut serta dalam pengadaan (bagi pegawai negeri/penyelenggara negara), dan menerima gratifikasi (bagi pegawai negeri/penyelenggara negara). Titik ujung korupsi adalah kleptokrasi, yang arti harafiahnya pemerintahan oleh para pencuri, dimana pura-pura bertindak jujur pun tidak ada sama sekali.

Menurut Transparansi Internasional, korupsi di Indonesia selama tahun 2012 menjadi perhatian dunia. Indonesia bahkan tergabung dalam 60 besar negara terkorup di dunia. Indonesia duduk di peringkat 118 dari daftar peringkat indeks persepsi korupsi 174 negara dunia. Namun jika mengacu poin tiap negara, Indonesia duduk di posisi 56 negara terkorup. (cpi.transparency.org, 29/10/13).

Akutnya permasalahan korupsi, tidak hanya di Indonesia namun juga dibeberapa negara maju, akibatnya negara mengalami kebangkrutan birokrasi. David Osborn dan Ted gaebler (mewirausahakan Birokrasi, Pustaka Biraman Pressindo, 2005) mensinyalir bagaimana birokrasi Amerika, yang 100 tahun lalu dipandang positif, kini semakin dirasakan lamban, tidak lincah, tidak bisa menyesuaikan dengan perubahan kebutuhan masyarakat. Birokrasi kota-kota yang ada di Amerika menjadi demikian gemuk dan korup, sehingga tidak bisa diharapkan lagi.

Dampak lain dari korusi adalah bagi kesejahtaraan, seperti apa yang di sampaikan oeh Abraham Samad (Ketua KPK), Indonesia adalah negeri yang kaya dan memiliki pemasukan besar. Dari sektor energi misalnya, negara bisa saja mendulang Rp 15 ribu triliun setiap tahun. Uang sebesar itu akan di dapat jika pemerintah mampu memaksa perusahaan tambang untuk membayar royalty sebesar 50 persen. Sebagai contoh, dalam setahun, Blok migas Mahakam bisa mendulang Rp 120 triliun, Blok Cepu sebesar Rp 190 triliun, dan Blok Madura senilai Rp 135 triliun. Kenapa pemerintah tidak bisa memaksa? Karena pengusaha telah membayar sogokan kepada pemerintah setempat. "Bahkan, sesungguhnya uang suap yang dibayarkan ke oknum pemerintah lebih besar dari royalti," ucapnya. (Tempo.co, 29/10/13). Beliau pun menambahkan seandainya uang sebanyak itu di bagikan kepada rakyat Indonesia maka tiap-tiap kepala keluarga akan memilikik penghasilan sekitar Rp 30 juta setiap bulan.

\section{REFORMASI BIROKRASI}

Menurut Eko Prasojo Wakil Menteri Pendayagunaan Aparatur Negara dan Reformasi Birokrasi (Wamen PAN dan RB). Ada tujuh realita kebobrokan birokrasi di Indonesia. pertama, pola pikir para birokrat terlalu sesuai aturan. Kedua, orientasi budaya kerja lemah. Ketiga, 
birokrasi secara organisasi terlalu gemuk. Keempat, perundang-undangan tidak harmonis. Kelima, banyak para birokrat ditempatkan pada posisi yang tidak sesuai kemampuannya. Keenam, kewenangan yang tumpang tindih atau overlapping. Ketujuh, pelayanan publik menjadi buruk. Selain itu, kuatnya ikatan antara para birokrat atau birokrasi dengan political authority; diorganisir secara hierarkis dan birokratis; serta memiliki monopoli. Hal tersebutlah yang menciptakan apa yang dinamai dengan budaya birokrasi.

Menurut mantan Menteri Negara Pendayagunaan Aparatur Negara, Ryaas Rasyid. Saat ini masalah terbesar bagi Indonesia adalah manajemen organisasi yang buruk, sehingga korupsi terus berjalan meskipun ada upaya pemerintah untuk memberantasnya. Sistem tata kelola organisasi yang tidak resisten terhadap penyimpangan dan penyelewengan itu, menjadi sarang persembunyian yang paling aman bagi para koruptor. "Indonesia memiliki struktur birokrasi yang paling gemuk di dunia, tidak ada tanda-tanda keberhasilan reformasi birokrasi jika perampingan organisasi tidak dilaksanakan," kata Ryaas.(Facebook.com, 21/3/12).

Dampak dari gemuknya struktur birokrasi di Indonesia menyebabkan cenderung permisif terhadap korupsi dan pungutan liar (high cost economy) dan menyebabkan pelayanan masyarakat menjadi tidak efisien karena banyaknya meja birokrasi (perijinan) yang harus dilalui sehingga pemakai jasa terdorong memberikan "uang jasa" agar urusan birokrasinya dapat dipercepat.

Secara umum, korupsi mengikis kemampuan institusi dari pemerintah, karena pengabaian prosedur, penyedotan sumber daya, dan pejabat diangkat atau dinaikan jabatan bukan karena prestasi. Pada saat yang bersamaan, korupsi mempersulit legitimasi pemerintahan. Sehingga ditempuhkan program pemerintah yakni reformasi Administrasi. Tujuan dari reformasi birokrasi adalah untuk mewujudkan pemerintahan yang bersih dari $\mathrm{KKN}$, pelayanan yang prima dan akuntabel khususnya dalam masyarakat dan dunia usaha.

Berbagai teori di munculkan untuk memperbaiki birokrasi di dunia tak terkecuali Indonesia. Pada awal tahun 1990an good governance masuk ke Indonesia sebagai solusi dari permasalahan birokrasi yang akut. Menurut Sjamsiar (2005,3) sebelum wacana good governance mendominasi arah reformasi pemerintahan di Indonesia, terminology seperti "less-government", "enterpreneural Government" dan sejenisnya sempat menjadi wacana yang dominan. Buku yang ditulis oleh Ted Gaebler dan David Osborn (1992), yaitu "reinventing government" telah menjadi rujukan bagi birokrasi di Indonesia dalam menyelenggarakan pemerintahan dengan sepuluh prinsipnya.

Beberapa tahun kemudian, teori Good Governance mengalami perkembangan dengan model New Public Manajement (NPM). NPM merupakan teori baru manajemen pubik yang beranggapan bahwa praktik manajemen sektor swasta adalah lebih baik dibandingkan dengan praktik manajemen sektor publik. Huges dkk. dalam Mahmudi (2010) Dalam Febriyanto (2013) mengatakan bahwa" untuk memperbaiki kinerja sektor publik perlu diadopsi beberapa paktik dan tekhnik manajemen yang diterapkan di sektor swasta kedalam organisasi sektor publik, seperti pengadopsian mekanisme pasar, kompetensi tender, dan privatisasi perusahaan-perusahaan publik.

Mengenai New Public Manajement Anthony B.L. Cheung, dalam Hermawan (2013) mengatakan bahwa tidak akan dengan mudah merubah secara mendasar posisi birokrasi sebagai salah satu kekuatan politik dan menggantinya dengan "public service delivery" yang menempatkan warganegara sebagai konsumen (customers is the king).

Prasojo dkk. Dalam Kurniawan (2007) menjelaskan mengenai pergeseran kata antara kewarganegaraan dengan konsumen. Seiring dengan diadopsinya pendekatan berorientasi pasar dalam new public manajement menyebabkan masyarakat diredefinisi sebagai konsumen atau klien dan karenanya memiliki implikasi terhadap pola hubungan antara pemerintah dengan masyarakat 
(Haque, 1999, 313). Dalam pola hubungan yang baru tersebut melibatkan adanya transaksi keuangan antara masyarakat dengan pemerintah dalam proses penyediaan pelayanan publik (Haque, 1999, 313). Karenanya menurut Haque (1999, 313) Dalam Kurniawan (2007), kondisi yang semacam ini khususnya di negara berkembang dapat merugikan bagi kelompok masyarakat miskin yang tidak memiliki kapasitas keuangan sebagai konsumen atau pengguna pelayanan.

Namun, benarkah teori transparansi sektor swasta lebih bisa dipertanggung jawabkan? Indonesia sebagai Negara emerging markets dalam Survei yang dilakukan oleh Political \& Economic Risk Consultancy yang berbasis di Hongkong, menjadikan Indonesia sebagai negara paling korup dari 16 negara di kawasan Asia Pasifik menurut survei persepsi korupsi 2011 terhadap pelaku bisnis (kompas.com. 4/11/2013). Di negara-negara berkembang, politisi dan pejabat pemerintah menerima suap dari kelompok swasta sebanyak 20 sampai 40 miliar US dolar atau setara dengan Rp 200 triliun sampai Rp 400 triliun setiap tahun. Suap itu dilakukan dengan cara terorganisasi dan nyaris tidak tersentuh hukum. Akibat korupsi oleh kelompok bisnis ke pejabat publik, harga yang dibayar tidak sekadar uang. Praktik itu secara langsung telah merusak kinerja perusahaan. Imbasnya, terjadi korupsi pasar yang melemahkan persaingan sehat, harga yang adil, dan efisiensi. Dampak terburuk lain adalah mempertahankan birokrasi, partai politik, dan pemerintahan yang korup (antikorupsi.org, 14/10/09).

Berdasarkan penelitian Smith dalam Utomo (2007: 205-206), terdapat berbagaia faktor penyebab buruknya pelayanan aparat birokrasi, antara lain: gaji yang rendah, sikap mental aparat pemerintah, kondisi ekonomi yang buruk; Administrasi yang lemah; dan kurangnya pengawasan, sehingga dari sisi inilah kita bisa melihat bahwa buruknya pelayanan birokrasi karena disebabkan oleh faktor-faktor yang saling terkait bukan disebabkan oleh faktor tunggal.

Sepriyanto (2002: 252-255) mengungkapkan bahwa setidaknya ada dua factor yang menyebabkan korupsi, yaitu: Faktor Individu, Paham materialism yang menjadikan harta sebagai tujuan hidup telah mengakar dalam diri individu bahkan juga Negara. Paham ini menyebabkan hilangnya budaya malu, rasa bersalah sekaligus pengendalian diri, menghadapi fenomena korupsi. Bahkan pada tingkatan tertentu, korupsi dipandang cara yang sah untuk 'bagi-bagi' rejeki, menjaga stabiitas masyarakat, serta alat untuk mengendalikan dukungan dan kesetiaan (politik). Tidaklah heran kalau kita lihat saat ini korupsi dilakukan secara berjama'ah.

Tentu saja, permasalahan individu ini tidak berdiri sendiri, karena menurut Ryaas Rasyid "korupsi yang telah mengakar di birokrasi pemerintah saat ini merupakan produk dari sistem administrasi yang sakit". Pola pendidikan yang materialisme, tata nilai (sosial, kemasyarakatan, keluarga) yang liberal, system ekonomi yang materialism, sehingga sistem sosial yang dibangun akan membentuk individu-individu yang mengagungkan harta dan kekayaan sebagai sumber hidunya. Sehingga lahirlah masyarakat yang individualistik sekaligus materialistic. Dan saat ini kita hidup dalam kondisi ini.

Faktor system, Besar kecilnya birokrasi dan wewenangnya, ditentukan oleh fungsi pemerintahan yang didefinisikan oleh system politik dan pemerintahan yang dipakai negara tersebut. Factor system yang rusak tidak hanya disebbakan oleh ideology yang rusak namun disebabkan implementasi system hukum yang lemah. System saat ini tidak menjalankan fungsinya sebagai lembaga pencegah korupsi namun juga ketidakmampuanya untuk memberikan efek jera bagi orang yang melakukan korupsi. Penegakan hukum setengah hati atas kasus-kasus korupsi bukan saja membuat para koruptor takut, tetapi juga sekaligus membuat penghormatan terhada hukum rendah.

Kitapun tidak dapat memungkiri system penggajian yang rendah menjadi salah satu sebab kelemahan system ini. Gemuknya struktur birokrasi kita menyebabkan tersedotnya anggaran 
pada belanja pegawai. Meskipun setiap tahun pemerintah melakukan remunerasi gaji PNS namun tidak diimbangi dengan pertumbuhan ekonomi sector riil tetap saja kesejahteraan hanya sebatas mimpi.

Sistem Sosial. Ditengah masyarakat yang menerapkan ideology kapitalisme saat ini nilai sosial yang hidup ditengah masyarakat adalah niali-nilai pragmatism, materialism, dan permissive. Sehingga menyebabkan Control sosial yang lemah. Strata yag berlaku dimasyarakat tetap antara si kaya dan si miskin tanpa melihat halal atau haram harta yang diperoleh. Kita tidak heran saat ini jika melihat ulama menjadi guru spiritual pejabat yang korup.

\section{PENGARUH POLITIK KEPENTINGAN}

Politik adalah usaha menggapai kehidupan yang lebih baik (Budiarjo. 2013:13). Mulai adanya keberadaan manusia, membentuk masyarakat dan mengatur kehidupan kolektif secara dengan baik mengingat masyarakat sering menghadapi terbatasnya sumber alam, atau perlu dicarisuatu cara distribusi sumber daya agar semua warga merasa bahagia dan puas. Ini adalah politik.

Bagaimana caranya mencapai tujuan terssebut? Usaha tersebut dapat dicapai dengan berbagai cara, yang kadang-kadang bertentangan satu dengan lainnya. Akan tetapi semua pengamat setuju bahwa tujuan itu hanya dapat dicapai jika memiliki kekuasaan suatu wilayah tertentu (negara atau sistem politik).

Politik dalam suatu negara berkaitan dengan masalah kekuasaan (power) pengambilan kekuasaan (decision making), kebijakan publik (public policy), dan alokasi atau distribusi (allocation or distribution).

Menurut Asad (dalam Kurnia, 2003) politik adalah menghimpun kekuatan; meningkatkan kualitas dan kuantitas kekuatan; mengawasi dan mengendalikan kekuatan; dan menggunakan kekuatan, untuk mencapai tujuan kekuasaan dalam negara dan institusi lainnya. Sedangkan menurut Isjwara (dalam Kurnia, 2003) politik adalah perjuangan untuk memperoleh kekuasaan; teknik menjalankan kekuasaan; masalah-masalah pelaksanaan dan kontrol kekuasaan; atau pembentukan kekuasaan.

Di samping itu politik juga dapat ditilik dari sudut pandang berbeda, yaitu antara lain:

1. politik adalah usaha yang ditempuh warga negara untuk mewujudkan kebaikan bersama (teori klasik Aristoteles)

2. politik adalah hal yang berkaitan dengan penyelenggaraan Pemerintahan dan Negara

3. politik merupakan kegiatan yang diarahkan untuk mendapatkan dan mempertahankan kekuasaan di masyarakat

4. politik adalah segala sesuatu tentang proses perumusan dan pelaksanaan kebijakan publik.

Dalam konteks memahami politik perlu dipahami beberapa kunci, antara lain: kekuasaan politik, legitimasi, sistem politik, perilaku politik, partisipasi politik, proses politik, dan juga tidak kalah pentingnya untuk mengetahui seluk beluk tentang partai politik.

Menurut Maksudi (2012) ketika seseorang mencoba untuk berusaha meraih kesejahteraan pribadinya melalui sumber yang tersedia, dan ketika mereka berupaya untuk mempengaruhi orang lain agar menerima pandangannya, maka mereka melihat dirinya sibuk dengan kegiatan (aktivitas) politik.

Praktek politik yang ada saat ini, memberikan gambaran bagaimana politik kepentingan terasa lebih kental, kita memahami bahwa keberadaan birokrasi sebagai mesin Negara yang paling mudah digunakan untuk mengontrol perilaku masyarakat sekaligus memanfaatkannya untuk mempertahankan kekuasaan ( eko Prasejo, 17/10/2007). 
Dalam konteks ini, pemerintah harus mampu memilah dan memastikan bahwa agenda reformasi birokrasi memang semata-sama merupakan agenda untuk memberikan pelayanan kepada masyarakat yang efektif dan efisien sehingga menghasilkan tujuan dari keberadaan pelayanan itu sendiri.

Melihat dari permasalahan ini, memang agenda reformasi birokrasi memunculkan tantangan tersendiri yang tidaklah mudah, karena politik reformasi birokrasi adalah hal yang kompleks karena melibatkan kepentingan politik dalam birokrasi. Padahal dalam berbagai praktek dan teori, reforasi birokrasi adalah proses politik yang membutuhkan dukungan politik dari pada pejabat politik yang terpilih. ( eko Prasejo, 17/10/2007).

\section{PENUTUP}

Reformasi birokrasi adalah agenda wajib yang harus dijalankan pemerintah, patologi birokrasi yang telah menjadi masalah akut menjadikan tangtangan tersendiri dalam agenda reformasi ini. Tantangan lain yang juga dihadapi adalah praktik politik pragmatism, jangan sampai reformasi birokrasi yang telah diagendakan kemudian berakhir hanya sebatas pada seremonial namun tidak meninggalkan pengaruh perbaikan dalam praktek pelayanan ditengah masyarakat.

\section{DAFTAR PUSTAKA}

Dwiyanto, Agus. 2009. Reformasi Birokrasi, Kepemimpinan dan Pelayanan Publik. Yogyakarta: Gava Media.

http://www.bbc.com/indonesia/berita_indonesia/2016/10/161011_indonesia_kemenhub_suap

http://www.ui.ac.id/download/kliping/171007/Politik_Reformasi_Birokrasi.pdf

Jamsudin, Syamsiar. 2005. Pemerintahan dan Kemitraan. Malang: Yayasan Pembangunan Nasional.

Jurnal Ilmiah Administrasi Publik \& Pembangunan, Edi Hermawan. New Publik Management dan Politik Birokrasi dalam Reformasi Birokrasi di Indonesia. Edisi Juli-Desember 2013

Jurnal Ilmu Adm Negara. Teguh Kurniawan. Pergeseran Paradigma Administrasi Publik: Dari Perilaku Model Klasik dan NPM ke Good Governancemore. Edisi 1 Januari 2007,

Jurnal. Iwan Ismi Febriyanto. Dialektika Kebijakan Publik: "Studi Komparasi dan teori New Public Manajement dengan Good Governance dalam Persfektif Kebijakan Publik. 20013

Kumorotomo, Wahyudi\&Pramusinto, Agus, 2009. Governance Reform di Indonesia. Yogyakarta: Gava Media.

Osborn, David \& Gaebler, Ted. 2005. Reinventing Government. PPM. Jakarta.

Sinambela, Lijan Poltak, 2008 Reformasi Pelayanan Publik. Jakarta: Bumi Aksara.

Utomo, Warsito. 2007. Administrasi Publik Baru Indonesia. Yogyakarta: Pustaka Pelajar. 
Wibawa, Samodra. 2005. Reformasi Administrasi Bunga Rampai Pemikiran Administrasi Negara/public. Yogyakarta: Gava Media. 